\title{
Medidas antropométricas de comprimento de lábio superior e filtro****
}

\author{
Anthropometrical measurements of the height of the upper lip and \\ length of the philtrum
}

\author{
Sibeli Daenecke* \\ Esther Mandelbaum Gonçalves Bianchini ** \\ Ana Paula Berberian V. da Silva ***
}

\section{* Fonoaudióloga do Centro de Especialização em Fonoaudiologia Clínica (CEFAC). Endereço para correspondência: Rua Martinho Leandro dos Santos, 146/204 - Florianópolis - SC. CEP 88040-050 (sibis@ig.com.br). \\ **Fonoaudióloga. Doutora em \\ Ciências - Fisiopatologia Experimental - Faculdade de Medicina da Universidade de São Paulo. Docente do CEFAC.}

***Fonoaudióloga. Pós-Doutora em Lingüística - Universidade Federal do Paraná. Docente do CEFAC.

****Trabalho Realizado no CEFAC.

Artigo de Pesquisa

Artigo Submetido a Avaliação por Pares

Conflito de Interesse: não

Recebido em 18.11.2005

Revisado em 27.12.2005; 31.07.2006; 12.09.2006; 07.11.2006.

Aceito para Publicação em 07.11.2006.

\begin{abstract}
Background: indirect anthropometrical measurements of the height of the upper lip and length of the philtrum. Aim: to describe the measurements of the height of the upper lip and length of the philtrum, extracted from video x-rays, in children with mixed dentition, relating these measurements to facial typology - medium and long -, to occlusion - Angle's class I and II - and to the rest position of the lips - with and without lip seal. Method: verification of 123 x-rays, in lateral norm, of children with ages between 7:7 and 11:10 years, 56 male and 67 female, extracted from archives of orthodontical documentation prior to treatment. Results: the T-Student test, with a significance level of 5\%, was used for the statistical analyses and the obtained results were: for the height of the upper lip no statistical difference was found considering the variables of face typology, occlusion and gender; there was no statistical difference for the measurements of the philtrum considering the variables of face typology and occlusion, but a statistically significant difference was found for the variable gender; a statistically significant difference was found for the height of the upper lip and length of the philtrum considering the variable rest position of the lips - with and without lip seal - being this a determinant factor for the measurements. This finding suggests that a direction of structural modifications may exist. Conclusion: the mean value for the height of the upper lip was established at $21 \mathrm{~mm}$; the mean value for the length of the philtrum was established at $12 \mathrm{~mm}$. It is important to consider the rest posture of the lips, during assessment and therapy, when taking the measurements of the height of the upper lip and length of the philtrum.
\end{abstract}

Key Words: Face; Measures; Cephalometric; Anthropometry; Child.

\section{Resumo}

Tema: medidas antropométricas faciais indiretas de lábio superior e filtro. Objetivo: descrever as medidas de lábio superior e filtro em crianças no período de dentição mista, extraídas de telerradiografias, relacionandoas aos tipos faciais médio e longo, aos padrões de oclusão classe I e II de Angle e à postura habitual de repouso com e sem selamento labial. Método: verificação de 123 traçados de telerradiografias em norma lateral de crianças, extraídas de arquivos de documentação ortodôntica antes do início do tratamento corretivo. As radiografias são de crianças com idades entre 7:7 anos e 11:10 anos, sendo 56 do gênero masculino e 67 do feminino. Resultados: na análise estatística foi utilizado o Teste-t de Student com significância de 5\% e obteve-se os resultados: para lábio superior não foi encontrada diferença estatisticamente significante levando em consideração as variáveis tipos de face, oclusão e sexo. Para as medidas de filtro não houve diferença estatisticamente significante considerando tipo de face e oclusão, porém houve diferença para variável gênero. Obteve-se diferença estatisticamente significante tanto para lábio superior quanto para filtro analisando a variável postura habitual de repouso com e sem selamento labial, sendo assim fator determinante para as medidas. Este fato indica que pode haver direcionamento de modificações estruturais. Conclusão: média para comprimento do lábio superior em telerradiografia ficou estabelecida em torno de 21mm; a média para filtro em torno de $12 \mathrm{~mm}$. É importante considerar postura labial de repouso durante avaliação e processo de terapia ao se realizar as medidas de lábio superior e filtro.

Palavras-Chave: Face; Medidas; Cefalometria; Antropometria; Criança. 


\section{Introduction}

In order to work in the orofacial area (one of the speech and language specialties) it's necessary to verify several aspects that are related to the lips, such as thickness, length, eversion, retraction, sealing, tonus, symmetry, color, saliva accumulation and nasolabial and mentolabial angles (Bianchini, 2001; Marchesan, 2003; Pierotti, 2003). These data establish a direct relation with the differential diagnosis and prognosis of the speech-language therapy. The use of the caliper, an instrument that measures dimensions precisely (Silva \& Cunha, 2003), allows to verify the lips and philtrum measures and other facial structures.

According to Junqueira (2002), Bianchini (2000, 2002) and Marchesan (2003), the oral breathing pattern may result in myofunctional disorders due to the lack of contact between the lips. Morphologically, the upper lip may undergo shortening, retraction and tonus alteration leading to incompetence or hypofunction. In many cases the lip sealing will only occur with an exaggerated help of the lower lip and consequent tension of the chin muscle (Bianchini, 2001). These characteristics may aggravate or lead to important morphological disorders in the face and mouth, such as those individuals with a tendency to long face (vertical growing pattern), Angle's class II, palate atresy, crossbite or openbite, vestibularization of the incisors, alteration of the tongue positioning and alteration of the body posture modifying, thus, the swallowing, chewing and the speech (Bianchini, 2000, 2001; Krakauer \& Guilherme, 2000; Parolo \& Bianchini, 2000; Pereira et al.,2001; Cunha et al., 2003; Felício et al., 2003; Jefferson, 2003; Jung et al., 2003; Lessa et al., 2005).

According to cephalometric analysis, the craniofacial skeleton variation may be classified, originating the several facial types - long, medium and short. The facial morphological growth pattern presents particular characteristics for each type. The medium face is characterized by a medium facial pattern, balanced thirds of the face, with an oval or medium dental arch. The short face is characterized by an horizontal growing, reduced lower third of the face (reduced lower facial height), overbite, closed mandibular angle, longer posterior cranial base, and wide dental arch. The long face presents a vertical growing pattern, longer/ enlarged inferior third of the face, open mandibular angle, and may present excessive bone in the posterior part of the maxilla, and anterior openbite, shorter posterior cranial base and long and narrow dental arch (Bianchini, 2001, 2002).
The facial types determine different muscle patterns and different oral functions performance. In the medium face, the muscle normally settles in/ to the facial adequate vertical proportion, not requesting functional adaptations. In the short face, the muscles are strong, specially the masseter muscle, and the upper lip may be thinner than the lower lip due to the little inferior face height. The anterior mandible slide is common in the speech articulation, specially in the phonemes /s/ and /z/, sometimes leading to a lateral interposition due to a posterior bilateral tongue thrust. In the long face, the muscles are generally flaccid and debilitated. Frequently the upper lip is functionally incompetent, with little mobility and the lips pressure determines a weakening in the articulation of the bilabial phonemes /p/, /b/ and /m/. The production of phonemes /t/, /d/, /n/, /l/ and /s/, /z/ may be altered due to the anterior tongue thrust (Marchesan, 2000; Bianchini, 2001, 2002; Rodrigues \& Rahal, 2003; Cardoso et al., 2005).

The facial pattern may of difficult solution when there is an increase of the anterior facial height, characteristic found in individuals with long face (Sabatoski et al., 2002). In these cases, the lip sealing may be more difficult to be obtained, and this is an important factor for the speech-language approach. Thus, it is necessary to create tongue posture adaptations allowing the nasal breathing without excessive compensatory efforts (Bianchini, 2001).

The different profile types correspond to the sagittal or to the antero-posterior facial patterns, that is, they depend on the maxillomandibular relation with the cranial base. According to Angle, they can be classified in class I, class II or class III.

In the class I type it is frequent the presence of a straight profile with a balance between the perioral muscles, chewing and tongue functions. The class II type may be characterized in different ways, presenting a convex profile due to the mandible size reduction, the maxilla projection or both in relation to the cranial base (Bianchini, 2002). These skeletal possibilities lead to functional adaptations characterized by: lifted upper lip with a reduced functionality, and everted lower lip occluding in the salience with the upper incisors due to its antero-posterior bone discrepancy. Hyperfunction of chin muscle contributing in the elevation of the lips' orbicular during the stomatognathic functions. Articulation distortions, specially of the bilabial phonemes when the labial occlusion is substituted by the occlusion of the lower lip with the upper 
incisors, of the sibilant phonemes when there is a mandible slide and tongue projection over the arcade's borders (Bianchini, 2001, 2002).

The morphological evaluation of the face may be done from the anthropometry, area that studies the proportions, weight and size measures of the human body (Farkas, 1994), resulting in objective data that can be compared, once the normality pattern of facial measures for the Caucasian population is already established (Allanson, 1997; Ward et al., 1998, 2000; Farkas et al., 2000).

In the direct anthropometry, the morphological evaluation is obtained by using the caliper or the metric tape taking out the measures directly from the subject's face. Nevertheless, in the indirect anthropometry the measures can be collected from the cephalometry of the soft tissue profile (Allanson et al.,1997).

A recent study aiming at establishing the relation between anthropometric and cephalometric measures and proportions of healthy Caucasian men and women, showed that there were no significant differences between the vertical anthropometric and cephalometric measures in the facial profile. In general, the normal cephalometric measures were lower than the anthropometric ones, some of them statistically significant (Budai et al., 2003).

In the medical anthropometry, 47 craniofacial points are described in the literature for the head and face measures (Allanson, 1997). Concerning the facial anthropometric measures, the height of the upper lip (sn-sto) corresponds to the distance between the subnasale (sn) and the lowest point of the upper lip (sto). The philtrum length (sn-ls) corresponds to the distance between the subnasale (sn) point and the upper lip (ls) (Farkas, 1994).

Normality data of anthropometrical facial measures are found in the literature of craniomaxillofacial surgery and orthodontics , nevertheless, the great majority refers to adults. According to Suguino et al. (1996), the height of the upper lip (sn-sto) in an adults is from 19 to $22 \mathrm{~mm}$, being larger in men than in women. Cattoni (2003) points out that in an adult the upper lip (snsto) varies between 21,2 to $26 \mathrm{~mm}$ for men and 17 to $23 \mathrm{~mm}$ for women. The height of the upper lip (snsto) is between 18,7 and $19,9 \mathrm{~mm}$ at six years of age, increasing a little at 12 years of age, remaining between 19,9 and 20,8 mm (Farkas et al., 1994). For Brazilian children aged between 6,10 and 12,11 years, the measures found were from 18,29 to 18,37 mm (Cattoni et al., 2003; Cattoni, 2004).

The philtrum length (sn-ls) is between 12,6 and $14,4 \mathrm{~mm}$ at 6 years of age, not occurring an increase of the structure at 12 years of age (Farkas et al., 1994). In a study carried out in Brazil with children ranging in age from 6,10 to 12,11 years, the measures found were from 12,74 to 13,74mm, larger in boys than in girls (Cattoni et al., 2003; Cattoni, 2004).

The interest in running this research came from the fact that there are a few references of upper lip and philtrum measures in Brazilian children under 12 years old. A significant number of subjects from this population look for speech-language therapy. Furthermore, there is an interest to know if the different types of face (medium and long), the occlusion (class I and class II), the gender (female and male) and the habitual resting posture of lips may interfere in those measures, once these patterns may determine particular muscular characteristics leading to interferences in the therapeutic proposal.

The aim of this study was to verify anthropometric measures of upper lip and philtrum of children, extracted from cephalometries, and to associate such measures to the facial types medium and long, to occlusion patterns of class I and class II, as well as to the resting posture of lips with and without lips sealing.

\section{Method}

This study was approved by the Research Ethics Committee of CEFAC (protocol number 066/ 04). The information were collected after the authorization of the orthodontists responsible for the archives of the studied orthodontic documentation obtained by the signing of the Informed Consent Term, consenting the conduction and publication of the results according to the resolution 196/96 (BRASIL. Resolução MS/CNS/CNEP nº 196/96, 10/10/1996).

One hundred and twenty three video x-rays in lateral norm of Brazilian children from 7 years and 7 months to 11 years and 10 months, 56 male and 67 female were selected from documentation archives of orthodontic clinics of Florianópolis city.

The following video $x$-rays criteria were considered in this study: mixed dentition with the complete eruption of the four permanent first molars; video x-rays taken before the beginning of the orthodontic treatment; long and medium facial patterns; occlusion patterns Class I and Class II.

All radiographies were requested by the responsible orthodontist before the beginning of the orthodontic treatment. The radiographic cases that didn't fulfill the inclusion criteria were not used in this study. 
Once the radiographies were selected, tracings of the anatomical structures and the identification of cephalometric reference points were done over a transparent acetate paper "Ultraphan", with the support of a light box. After the outline of the cephalogram, the measurements of the defined variables were performed. All anatomical structures and the cephalometric points were identified by only one person, the measures were taken twice using a caliper (digital Starret series 727, with a millimeter approximation) and the craniofacial points were marked in the radiographic sketch, as suggested in facial anthropometric, odontological and speechlanguage researches (Allanson, 1997; Bianchini, 2002; Cattoni et al., 2003; Cattoni, 2004). In this research, the average values obtained in each studied category for height of the upper lip (sn-sto and sn-stms) and length of philtrum (sn-ls) were used.

The Steiner analysis (Martins \& Ferreira, 1996) was adopted in this study in order to determine the occlusion type (Class I, Class II and Class III). The values were obtained through the (SNA) tracings being $S$ the virtual point in the center of the cella turcica, $\mathrm{N}$ the nasion point and $\mathrm{A}$, the deepest part of the subspinal concavity - and (SNB) - being B the position of deepest concavity on anterior profile of mandibular symphysis - resulting in the (ANB) angle that determines the occlusion pattern and indicates the face convexity, as shows Figure 1.

In order to determine the facial typology, that is, medium or long face, the Gebeck and Merrifield (1989) analysis and the Horn (1992) analysis were used. The Horn analysis identifies the index of facial height (IAF), by the ratio between the posterior facial height (AFP) and the anterior facial height (AFA), being $\mathrm{IAF}=\mathrm{AFP} / \mathrm{AFA}$, with a normal variation between 65 and $75 \%$ or 0,65 and 0,75 . A long face was considered when the index was below 0,65 , medium face between 0,65 and 0,75 and short face above 0,75 (figures 2 and 3). Cases with indexes below 0,55 and above 0,85 would have surgical indication (Horn, 1992; Locks et al., 2005).

The following procedures were adopted for the outline of the cephalogram:

1. Delimitation of the dentoskeletal structures (Bianchini, 2002); anterior and posterior cranial bases; profile of the glabela and nasal bones; pterigo maxillary fossa; maxilla; mandible; central upper and lower incisors; soft profile.

2. Delimitation of the cephalometric points (Bianchini, 2002); N (nasion) - the most anterior point of the frontonasal suture. S (sella turcica) -virtual point in the center of the sella turcica. A - Position of deepest concavity on anterior profile of maxilla, representing the limit between the bony and the alveolar base of the anterior maxilla; B - position of deepest concavity on anterior profile of mandibular symphysis, representing the limit between the bony and the alveolar base of the anterior mandible; - ENA (anterior nasal spine)- the most anterior point of the maxilla - ENP (posterior nasal spine) - the most posterior point of the maxilla - Me (menton) - the lowest point of the mandibular symphysis border, in the intersection with the lower border of the mandible -Ar (articular) - intersection point of the lower surface of the posterior cranial base with the posterior surface of the mandibular condylar.

3. Lines, points e plans according the Gebeck and Merrifield's (1989) analysis - PP (palatal plane) junction of ENA and ENP - PM (mandibular plane) - represented by the line that passes by the Me point and by the lowest point in the gonium region - Ar-PM (line Ar-PM) - junction of point Ar with $\mathrm{PM}$, tangent to the posterior border of the ascending branch of the mandible - PP-Me (line PP-Me) - perpendicular to the palatal plane, that unites this plane to the Me point.

4. Measures according to the Gebeck and Merrifield's (1989) analysis - AFA (anterior facial height) - distance between the PP point and the Me point, measured over the PP-Me line - AFP (posterior facial height) - distance between the Ar point and the PM point, measured over the Ar-PM line..

5. Facial height index according to Horn (1992): IAF (facial height index) - ratio between the posterior facial height and the anterior facial height (AFP/ AFA).

6. Soft tissue cephalometric points according to Farkas (1994) and to Legan and Burstone (1980): sn (subnasale); ls (upper lip); sto (estomion) - with lips sealing; stms (the lowest point of the upper lip) - without lips sealing.

7. Soft tissues measures according to Farkas (1994) and to Legan and Burstone (1980); philtrum (snls); upper lip (sn-sto) - with sealing; upper lip (snstms) - without sealing.

In order to standardize the upper lip measurement with lips sealing (sn-sto), without lips sealing (sn-stms) and the philtrum measurement (sn-ls), the points were first prolonged with a set square and then measured with the caliper, as indicated in Figures 4, 5 and 6. The points referred by Farkas (1994) were adopted as anthropometric standardization for the upper lip with lips sealing and the ones referred Legan and Burstone (1980) were adopted for the upper lip without lip sealing. 
FIGURA 1. ANB angle.

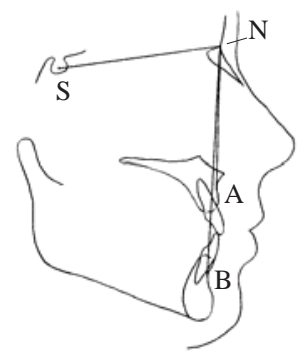

FIGURA 2. Measures used by Gebeck and Merrifield (1989).

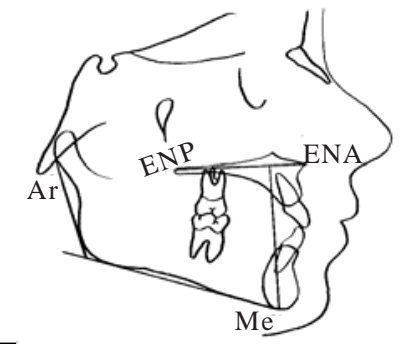

FIGURA 3. Dimensions used in the IAF ( Horn ,1992).

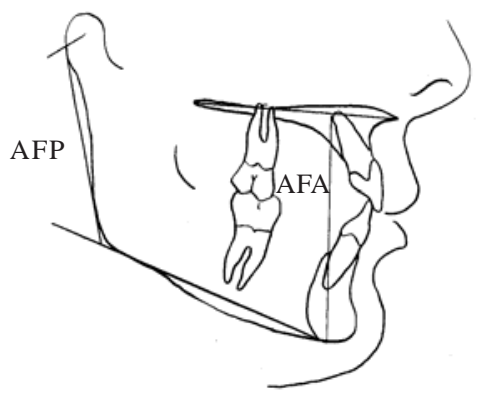

\section{Results}

The sample was characterized through the descriptive data analysis (average, standard deviation, trust interval and minimum and maximum values). The averages of the upper lip (sn-sto) and philtrum (sn-ls) measures obtained in the different types of face, occlusion, gender and habitual resting position of lips were compared in order to verify the existence of significant statistical differences between the collected samples. The two samples t-Student test, presuming different variances, and the Pearson (r) coefficient, appropriate to describe the relation of two quantitative variables, were used. The
FIGURA 4. Upper lip measure (sn-sto) with sealing.

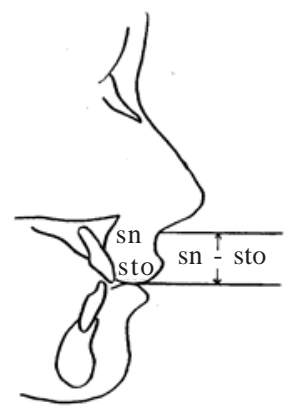

FIGURA 5. Upper lip measure (sn-stms) without sealing.

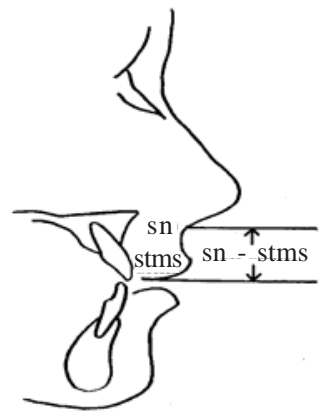

FIGURA 6. Philtrum measure (sn-ls).

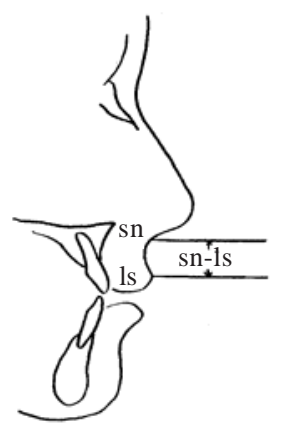

significance level adopted was $5 \%$.

The total sample was $123 \mathrm{x}$-rays tracings, from which 69 (56,6\%) were of medium face and 54 (43,3\%) of long face; 56 (45,5\%) were male and 67 (54,5\%), female. It was found: $61(49,6 \%)$ with resting posture with lips sealing and $62(50,4 \%)$ with resting posture without lips sealing. Concerning the occlusion, it was found 59 (48,0\%) Angle's class I and 64 (52,0\%) Angle's class II.

The height of the upper lip (sn-sto) varied from $16,0 \mathrm{~mm}$ to $27,3 \mathrm{~mm}$ in the total sample. The minimum and maximum values are showed in Table 1. 
The averages obtained for each studied variables are in table 2 .

Concerning the comparative data of the average facial anthropometric measures of upper lip (sn-sto) in different types of face and occlusion, there was no significant statistical difference between the averages for the variables: type of face, gender and Class I and Class II types of occlusion. However, for the variable resting posture of lips with or without sealing there was a significant statistical difference in the upper lip height (sn-sto and sn-stms), as showed in Table 2.

The philtrum length (sn-ls) varied from 6,4mm to $18,9 \mathrm{~mm}$. The minimum and maximum values found are described in Table 3.

The averages obtained for each studied variable are described in table 4.

Regarding the comparative data of the averages for the facial anthropometric measures of philtrum (sn-ls) in the different types of face and occlusion, no statistical difference was found between the averages for the variables type of face and of occlusion. For the variable gender, there was a significant statistical difference, as well as for the comparison of the philtrum length (sn-ls) between the averages of resting posture of lips with and without lips sealing, as described in Table 4.

Analyzing the greater incidence of several values independently of the variables, it was observed greater cumulative percentage for the height of the upper lip (so-sto) between 20,52 and 22,77mm (Table $5)$. For the philtrum length (sn-ls), the greater cumulative percentage was between 11,39 and 13,98mm (Table 6).

The data analysis shows that there was a moderate positive correlation $(r=+0,7599)$ among the measures of the 123 analyzed tracings. Therefore, the greater the philtrum measure (sn-ls), it is observed an increase in the upper lip measure (sn-sto), according to a linear equation $(y=0,8839 x+10,205)$. A more significant statistics is the determination coefficient (square r), that provides us with the variation percentage from one variable to another. The result for $r=0,7599$, was square $r=0,58$, meaning that $58 \%$ of the variation of points are close to the two group averages and that $42 \%$ are not correlated.

TABLE 1. Minimum and maximum values of upper lip length (sn-sto) for each studied variable.

\begin{tabular}{|c|c|c|c|c|c|c|c|c|}
\hline Data & $\begin{array}{l}\text { Medium } \\
\text { face }\end{array}$ & Long face & male & female & Class I & Class II & $\begin{array}{l}\text { Resting lips } \\
\text { posture without } \\
\text { sealing }\end{array}$ & $\begin{array}{l}\text { Resting lips } \\
\text { posture with } \\
\text { sealing }\end{array}$ \\
\hline Minimum (mm) & 16,04 & 16,39 & 16,39 & 16,04 & 16,04 & 16,39 & 16,04 & 16,04 \\
\hline Maximum (mm) & 26,45 & 27,25 & 27,25 & 26,64 & 27,25 & 26,64 & 25,29 & 27,25 \\
\hline
\end{tabular}

TABLE 2. Average values of upper lip (sn-sto) for each studied variable.

\begin{tabular}{|c|c|c|c|c|c|c|c|c|}
\hline \multicolumn{9}{|c|}{ Anthropometric Measures } \\
\hline & Group & $\mathbf{N}$ & $\begin{array}{c}\text { Average } \\
\text { (mm) }\end{array}$ & $\begin{array}{c}\text { IC 95\% } \\
\text { (average) }\end{array}$ & $\begin{array}{l}\text { Standard } \\
\text { deviation }\end{array}$ & t value & & $\begin{array}{c}\text { bicaudal } \\
\text { critical t } \\
(+ \text { or }-)\end{array}$ \\
\hline Upper lip & - & 123 & 21,25 & $20,85-21,65$ & 2,25 & & & \\
\hline \multirow{2}{*}{ Face } & Medium & 69 & 20,99 & $20,46-21,51$ & 2,23 & \multirow{2}{*}{ Medium $=$ long } & $\mathrm{t}=-1,459$ & 1,9812 \\
\hline & Long & 54 & 21,58 & $20,98-22,19$ & 2,26 & & & \\
\hline \multirow[b]{2}{*}{ Gender } & Male & 56 & 21,53 & $20,96-22,10$ & 2,18 & \multirow[b]{2}{*}{ Male. = Female. } & $\mathrm{t}=1,271$ & 1,9601 \\
\hline & Female & 67 & 21,01 & $20,46-21,57$ & 2,30 & & & \\
\hline \multirow[b]{2}{*}{ Class } & I & 59 & 21,20 & $20,65-21,75$ & 2,15 & \multirow[b]{2}{*}{ Class I = Class II } & $t=-0,239$ & 1,9798 \\
\hline & II & 64 & 21,30 & $20,72-21,68$ & 2,37 & & & \\
\hline \multirow{2}{*}{$\begin{array}{l}\text { Resting } \\
\text { lip } \\
\text { posture }\end{array}$} & $\begin{array}{l}\text { without } \\
\text { sealing }\end{array}$ & 62 & 20,37 & $19,66-20,87$ & 2,02 & \multirow[t]{2}{*}{$\begin{array}{c}\text { without sealing with } \\
\text { sealing }\end{array}$} & \multirow[t]{2}{*}{$t=-4,734$} & \multirow[t]{2}{*}{1,9799} \\
\hline & with sealing & 61 & 22,15 & $21,61-22,68$ & 2,14 & & & \\
\hline
\end{tabular}


TABLE 3. Minimum and maximum values of the length of the philtrum (sn-ls) for each studied variable.

\begin{tabular}{lcccccccc}
\hline Data & Medium face & Long face & male & female & Class I & Class II & $\begin{array}{c}\text { Resting lip } \\
\text { posture } \\
\text { without } \\
\text { sealing }\end{array}$ & $\begin{array}{c}\text { Resting lip } \\
\text { posture with } \\
\text { sealing }\end{array}$ \\
\hline imum (mm) & 8,41 & 6,41 & 9,91 & 6,41 & 8,41 & 6,41 & 6,41 & 9,91 \\
\hline imum (mm) & 17,01 & 18,87 & 18,87 & 16,72 & 18,87 & 17,01 & 17,01 & 18,87 \\
\hline
\end{tabular}

TABLE 4. Average values of philtrum length (sn-ls) for each studied variable.

\begin{tabular}{|c|c|c|c|c|c|c|c|c|}
\hline \multicolumn{9}{|c|}{ Anthropometric measures } \\
\hline & Group & $\mathbf{n}$ & $\begin{array}{l}\text { Average } \\
\text { (mm) }\end{array}$ & IC $95 \%$ (average) & $\begin{array}{l}\text { Standard } \\
\text { Deviation } \\
\text { (S) }\end{array}$ & T Value & & $\begin{array}{l}\text { bicaudal } \\
\text { critical t } \\
\text { (+ or }-)\end{array}$ \\
\hline Philtrum & & 123 & 12,495 & $12,152-12,838$ & 1,940 & & & \\
\hline Face & $\begin{array}{l}\text { Average } \\
\text { Long }\end{array}$ & $\begin{array}{l}69 \\
54 \\
\end{array}$ & $\begin{array}{l}12,41 \\
12,60\end{array}$ & $\begin{array}{l}11,97-12,85 \\
12,06-13,14\end{array}$ & $\begin{array}{l}1,87 \\
2,03 \\
\end{array}$ & Average $=$ long & $\mathrm{T}=-0,53$ & 1,982 \\
\hline Gender & $\begin{array}{l}\text { Male } \\
\text { Female }\end{array}$ & $\begin{array}{l}56 \\
67\end{array}$ & $\begin{array}{l}12,89 \\
12,16\end{array}$ & $\begin{array}{l}12,44-13,34 \\
11,67-12,65\end{array}$ & $\begin{array}{l}1,72 \\
2,06\end{array}$ & Male. Female. & $\mathrm{T}=2,15$ & 1,980 \\
\hline Class & $\begin{array}{l}\text { I } \\
\text { II }\end{array}$ & $\begin{array}{l}59 \\
64 \\
\end{array}$ & $\begin{array}{l}12,57 \\
12,42 \\
\end{array}$ & $\begin{array}{l}12,07-13,07 \\
11,95-12,89\end{array}$ & $\begin{array}{l}1,97 \\
1,93\end{array}$ & Class I = Class II & $\mathrm{T}=0,43$ & 1,980 \\
\hline $\begin{array}{l}\text { Resting lip } \\
\text { posture }\end{array}$ & $\begin{array}{l}\text { Without } \\
\text { sealing } \\
\text { With } \\
\text { sealing }\end{array}$ & 62 & 11,70 & $\begin{array}{l}11,25-12,15 \\
12,87-13,74\end{array}$ & $\begin{array}{l}1,82 \\
1,73\end{array}$ & $\begin{array}{l}\text { Without sealing } \\
\text { With sealing }\end{array}$ & $\mathrm{T}=-5,03$ & 1,980 \\
\hline
\end{tabular}

Mm = millimeters; IC = trust interval; $\mathrm{S}=$ Standard deviation of the sample; $\mathrm{n}=$ number of samples

TABLE 5. Shows the greater incidence of the values independently of the variables for the upper lip (sn-sto).

\begin{tabular}{|c|c|c|c|c|c|c|}
\hline \multicolumn{7}{|c|}{ Upper lip measure (mm) } \\
\hline Lips & Group & Track I & Track II & $\mathbf{N}^{\circ}$ philtrum & \% Relative & \% Accumulated \\
\hline 1 & $16,04 \mid---18,28$ & 16,04 & 18,28 & 8 & $7 \%$ & $6,5 \%$ \\
\hline 2 & $18,28 \mid---20,52$ & 18,28 & 20,52 & 40 & $33 \%$ & $39,0 \%$ \\
\hline 3 & $\begin{array}{l}10,-0 \mid \\
20,52 \mid--22,77\end{array}$ & 20,52 & 22,77 & 44 & $35,8 \%$ & $74,8 \%$ \\
\hline 4 & $22,77 \mid---25,01$ & 22,77 & 25,01 & 25 & $20 \%$ & $95,1 \%$ \\
\hline 5 & $25,01 \mid---27,25$ & 25,01 & 27,25 & 6 & $5 \%$ & $100,0 \%$ \\
\hline Total & & & & 123 & & \\
\hline
\end{tabular}

Most of the sample presented the values showed in line 3 for the upper lip height (sn-sto).

TABLE 6. Shows the greater incidence of the values independently of the variables for the philtrum (sn-ls)

\begin{tabular}{|c|c|c|c|c|c|c|}
\hline \multicolumn{7}{|c|}{ Philtrum measure (mm) } \\
\hline Lips & Group & Track I & Track II & $\mathbf{N}^{\circ}$ Philtrum & \% Relative & $\%$ Accumulated \\
\hline 1 & $6,41 \mid---\quad 8,90$ & 6,41 & 8,90 & 5 & $4 \%$ & $4,1 \%$ \\
\hline 2 & $\begin{array}{l}8,90 \mid---11,39 \\
\end{array}$ & 8,90 & 11,39 & 30 & $24 \%$ & $28,5 \%$ \\
\hline 3 & $11,39 \mid---13,89$ & 11,39 & 13,89 & 60 & $48,8 \%$ & $77,2 \%$ \\
\hline 4 & $13,89 \mid---16,38$ & 13,89 & 16,38 & 24 & $20 \%$ & $96,7 \%$ \\
\hline 5 & $16,38|--| 18,87$ & 16,38 & 18,87 & 4 & $3 \%$ & $100,0 \%$ \\
\hline Total & & & & 123 & & \\
\hline
\end{tabular}

Most of the sample presented the values showed in line 3 for the philtrum (sn-ls). 


\section{Discussion}

From the results obtained, it was possible to describe the averages of facial measures using the indirect anthropometry through video $\mathrm{x}$-rays, and to establish the correlation between the studied categories. Although the facial anthropometric measures studied in this research are minimal, compared to what is proposed by the anthropometry (Farkas, 1994), they can provide data on the morphology and height of the upper lip (sn-sto) and length of the philtrum (sn-ls) in different types of face, gender, occlusion and resting position of lips. The anthropometric measures of upper lip (sn-sto), philtrum (sn-ls) and craniofacial points found in this study agree with publications of the odontologic and speechlanguage areas (Legan, 1980; Farkas, 1994; Bianchini, 2002; Cattoni et al., 2003; Cattoni, 2004).

In the literature concerning normality patterns of facial measures, there is a predominance of measurements in adults, however in the international literature (Farkas, 1994) and in some recent national researches (Cattoni et al., 2003; Cattoni, 2004), there are normality references of the upper lip (sn-sto) and philtrum (sn-ls) measures in the age range studied in this research.

As observed in this sample, the averages of the values obtained for the height of upper lip (snsto) in all categories studied were higher, although close to those verified in other studies with the same age group (Farkas et al., 1994; Cattoni et al., 2003; Cattoni, 2004). It was observed that the averages were closer to the adult's measures (Suguino et al., 1996; Cattoni, 2003). Probably because this was an objective study through video $\mathrm{x}$-rays, the measurements precision could show differences regarding facial anthropometric studies, once the soft tissue even when delimited makes difficult the precision of the measures. Studies demonstrate that the measures obtained with video $\mathrm{X}$-rays are usually lower or the same as the data obtained directly from the subject's face, which was not proved in this research (Budai et al., 2003).

There was no significant statistical difference for the height of the upper lip (sn-sto) considering the variables type of face, gender and occlusion, which means that these variables seem not to interfere in the height of the upper lip (sn-sto) in the population of this research's sample. Thus, the variable gender does not appear to interfere in the height of the upper lip measures (sn-sto), although higher values were found for the male gender in previous studies (Suguino et al., 1996; Cattoni 2004).

Concerning the upper lip height in relation to the type of face, when analyzing the data individually it is observed that despite the slightly higher values in the long faces, the averages are very similar between the two facial types and are within the reference values mentioned previously (Farkas, 1994; Suguino et al., 1996; Cattoni, 2003; Cattoni 2004). This confirms that the type of face did not interfere in the height of the upper lip (snsto). It can be concluded, then, that part of the clinical problems related to the lips sealing difficulties in subjects with long face may not be directly related to the structure of the upper lip (sn-sto), but to the increase of the maxilla height, not characterizing a short upper lip (Bianchini, 2001; Jung et al., 2003).

A data of clinical importance was the observation of significant difference of upper lip (sn-sto) and of philtrum (sn-ls) for the variables resting posture with and without lips sealing, suggesting functional data that may be interesting for the speech-language area.

The average values either of upper lip (sn-sto) as of philtrum (sn-ls) were higher for the resting position with lips sealing than without lips sealing, being this difference statistically significant. These data suggest that the precision of the lips sealing directs structural modifications in the soft tissue (Bianchini, 2000; Parolo \& Bianchini, 2000; Bianchini, 2001; Marchesan, 2003) and, when these modifications are related to the tonus decrease, they may affect the positioning and the occlusion of antero-upper teeth (Jung et al., 2003), independently of the initial cause that resulted in the presence or not of the sealing. The methodology defined in this research does not allow interferences regarding the causes or possible determinant factors of the lip sealing, once the measures were obtained through video $x$-rays, without a direct contact with the individuals.

The averages of upper lip height (sn-ls) found in this study in all studied variables are closer to those pointed in the literature as reference values (Farkas, 1994; Cattoni et al., 2003; Cattoni, 2004). There was no significant statistical difference for the length of the philtrum (sn-ls) in the variable type of face and type of occlusion. Despite the significant difference pointed by the statistical test for the male and female genders ( $t=2,15$ and critical 
$t=1,980$ ), the data are not clinically significant.

Concerning the greater incidence of the several values obtained independently of the variable, the results indicated that in $58 \%$ of the sample there is a correlation between the upper lip and the philtrum size, that is, the longer the philtrum (sn-ls), the longer the upper lip (sn-sto). In $42 \%$ of the sample there was no correlation between these measures, which may be associated to the individual characteristics, such as labial thickness, eversion, presence or absence of lip sealing and nasolabial angle greater than 90 degrees, aspects not measured in this research.

Therefore, the measures of philtrum (sn-ls) and of upper lip (sn-sto) may be complementary; however, as there was a moderate positive relation, and not a strong relation, between them it's indicated that during the speech-language evaluation and therapeutic process both measures are used, the philtrum (sn-ls) and the upper lip (snsto), and not just the isolated analysis of one of them.

\section{Conclusion}

The characterization of the upper lip (sn-sto) and philtrum (sn-ls) measures in children with medium and long facial types, with Angle's occlusion patterns class I and class II, as well as resting posture of lips using cephalometric measures show that:

. the average for the upper lip measure (sn-sto) was around $21 \mathrm{~mm}$;

. the average for the philtrum measure (sn-ls) was around $12 \mathrm{~mm}$;

. the variables type of face, occlusion pattern and gender didn't seem to interfere in the height of the upper lip (sn-sto) and the length of the philtrum (sn-ls), and the averages were close to the reference values;

. the variable resting posture of lips with and without sealing was a determinant factor for the height of the upper lip (sn-sto) and length of the philtrum (sn-ls), suggesting that there might be a direction of structural changes;

. during the evaluation and subsequent reevaluations and/or patients control, the upper lip and the philtrum can be measured altogether, once there was an important degree of correlation between these measures.

\section{References}

ALLANSON, J. E. Objective techniques for craniofacial assesment: what are the choices? Am. J. Med. Genet., New York, v. 70, n. 1, p. 1-5, may 1997.

BIANCHINI, E. M. G. Avaliação fonoaudiológica da motricidade oral: anamnese, exame clínico, o quê e por que avaliar. In: BIANCHINI, E. M. G. Articulação temporomandibular: implicações, limitações e possibilidades fonoaudiológicas. Carapicuiba (SP): PróFono, 2000. p. 191-253.

BIANCHINI, E. M. G. Avaliação fonoaudiológica da motricidade oral: distúrbios miofuncionais orais ou situações adaptativas. Dent. Press Ortodon. Ortop. Fac., Maringá (PR), v. 6, n. 3, p. 73-82, maio-jun. 2001.

BIANCHINI, E. M. G. A cefalometria nas alterações miofuncionais orais: diagnóstico e tratamento. 5. ed. Barueri (SP): Pró-Fono, 2002.

BUDAI, M.; FARKAS, L. G.; TOMPSON, B.; KATIC, M.; FORREST, C. R. Relation between anthropometric measurements and proportions of the face of healthy young white adult men and women. J. Craniofac. Surg., Tampa (FL), v. 14, n. 3, p. 154-163, mar. 2003.

CARDOSO, M. A.; BERTOZ, F. A.; FILHO, L. C.; REIS, S. A. R. Características cefalométricas do padrão face longa. Dent. Press Ortodon. Ortop. Fac., Maringá (PR), v. 10, n. 2, p. 29-43, mar.-abr. 2005.
CATTONI, D. M. Avaliação quantitativa das estruturas orofaciais. In: KRAKAUER, L.; DI FRANCESCO, R.; MARCHESAN, I. Q. (Org). Respiração Oral: abordagem interdisciplinar. São José dos Campos: Pulso, 2003. p. 81-88.

CATTONI, D. M. Medidas e proporções faciais em crianças: contribuições para a avaliação miofuncional orofacial. Pró-Fono R. Atual. Cient., Barueri (SP), v. 10, n. 1, p. 7-18, jan.-abr. 2004.

CATTONI, D. M.; FERNADES, F. D. M.; MARCHESAN, I. Q.; LATORRE, M. R. D. Medidas antropométricas faciais em crianças: segundo período de dentição mista. $R$. Cefac, São Paulo, v. 5, n. 1, p. 21-29, jan.-mar. 2003.

CUNHA, D. A.; SILVA, H. J.; FONTES, M. L.; PAIXÃO, C.; MACIEL, A. A reeducação postural global (RPG): contribuições no paciente respirador oral em fonoterapia. R. Soc. Bras. Fono., São Paulo, v. 7, n. 2, p. 53-59, abr.-jun. 2003.

FARKAS, L. G. Examination. In: FARKAS, L. G. (Ed.). Anthropomrtry of the head and face. 2. ed. New York: Raven Press, 1994. p. 3-56.

FARKAS, L. G.; HRECZKO, T. M.; KATIC, M. J. Craniofacial norms in north american caucasians from birth (one year) to young adulthood. In: FARKAS, L. G. (Ed). Anthropometry of the head and face. 2. ed. New York: Raven Press, 1994. p. 241-312. 
FARKAS, L. G.; FORREST, C. R.; PHILLIPS, J. H. Comparison of the morphology of the "cleft face" and normal face: defining the anthropometric differences. J. Craniofac. Surg., Tampa (FL), v. 11, n. 2, p. 76-82, mar. 2000.

FELÍCIO, C. M.; FERREIRA-JERONYMO, R. R.; FERRIOLLI, B. H. V. M.; FREITAS, R. L. R. G. Análise da associação entre sucção, condições miofuncionais orais e fala. Pró-Fono R. Atual. Cient., Barueri (SP), v. 15, n. 1, p. 31-40, jan.-abr. 2003.

GEBECK, R. T.; MERRIFIELD, L. L. Analysis: concepts and values. J. Charles Tweed Found., Tucson (AZ), v. 17, p. 19-48, apr. 1989. part. 2.

HORN, A. J. Facial heihgt index. Am. J. Orthod., v. 102, p. 180-186, 1992.

JEFFERSON, Y. Orthodontic diagnosis in young children: beyoud dental malocclusions. Gen. Dent., v. 51, n. 2, p. 104-111, mar.-abr. 2003.

JUNG, M. H.; YANG, W. S.; NAHM. D. S. Effects of upper lip closing force on craniofacial structures. Am. J. Orthod. Dentofac. Orthop., Seattle (WA), v. 123, n. 1, p. 58-63, jan. 2003.

JUNQUEIRA, P. Respiração oral: considerações fonoaudiológicas. In: JUNQUEIRA, P.; DAUDEN, A. T. B. C. (Org.). Aspectos atuais em terapia fonoaudiológica. São Paulo: Pancast, 2002. v. 2, cap. 1, p. 9-16.

KRAKAUER, L. H.; GUILHERME, A. Relação entre respiração bucal e alterações posturais em crianças: uma análise descritiva. Dent. Press Ortodon. Ortop. Fac., Maringá (PR), v. 5, n. 5, p. 85-92, set.-out. 2000.

LEGAN, H. L.; BURSTONE, C. J. Soft tissue cephalometric analysis for orthognathic surgery. J. Oral Surg., St. Louis (MO), v. 38, n. 10, p. 744-751, oct. 1980.

LESSA, F. C. R.; ENOKI, C.; FERES, M. F. N.; VALERA, F. C. P.; LiMA, W. T. A.; MATSUMOTO, M. A. N. Influência do padrão respiratório na morfologia craniofacial. R. Bras. Otorrinolaringol., São Paulo, v. 71, n. 2, p. 156-160, mar.-abr. 2005.

LOCKS, A.; SAKIMA, T.; PINTO, A. S.; RITTER, D. E. Estudo cefalométrico das alturas faciais anterior e posterior, em crianças brasileiras, portadoras de má oclusão Classe I de Angle, na fase da dentadura mista. Dent. Press Ortodon. Ortop. Fac., Maringá (PR), v. 10, n. 2, p. 8795, mar.-abr. 2005.

MARCHESAN, I. Q. The speech pathology treatment with alterations of the stomatognathic system. Int. J. Orofac. Myol., Denver (CO), v. 26, p. 5-12, nov. 2000.
MARCHESAN, I. Q. Protocolo de avaliação miofuncional orofacial. In: KRAKAUER, L.; DIFRANCESCO, R.; MARCHESAN, I. Q. (Org). Respiração Oral: abordagem interdisciplinar. São José dos Campos: Pulso, 2003. p. 5567.

MARTINS, A. S.; FERREIRA, F. A. C. Análises cefalométricas: Tweed e Steiner. In: FERREIRA, F. V. Ortodontia: diagnóstico e planejamento clínico. São Paulo: Artes Médicas, 1996. p. 323-328.

PAROLO, A. M. F.; BIANCHINI, E. M. G. Pacientes portadores de respiração oral: uma visão fonoaudiológica. Dent. Press Ortodon. Ortop. Fac., Maringá (PR), v. 5, n. 2, p. 76-81, mar.-abr. 2000.

PEREIRA, F. C.; MONTONAGA, S. M.; FARIA, P. M.; MATSUMOTO, M. A. N.; TRAWITZKI, L. Y. V.; LIMA, S. A.; LIMA, W. T. A. Avaliação cefalométrica e miofuncional em respiradores bucais. $R$. Bras. Otorrinolaringol., São Paulo, v. 67, n. 1, p. 43-49, jan.-fev. 2001.

PIEROTTI, S. Entrevista e exame. In: KRAKAUER, L. H.; DI FRANCESCO, R. C.; MARCHESAN, I. Q. (Org.). Respiração oral: abordagem interdisciplinar. São josé dos Campos: Pulso, 2003. p. 47-53.

RODRIGUES, K. A.; RAHAL, A. A influência da tipologia facial na atividade eletromiográfica do músculo masseter durante o apertamento dental em máxima intercuspidação. R. Cefac, São Paulo, v. 5, n. 2, p. 127-130, abr.-jun. 2003.

SABATOSKI, C. V.; MARUO, H.; CAMARGO, E. S.; OLIVEIRA, J. H. G. Estudo comparativo de dimensões verticais e horizontais entre crianças respiradoras bucais e nasais. J. Bras. Ortodon. Ortop. Fac., Curitiba (PR), v. 7, n. 39, p. 246-257, maio-jun. 2002.

SILVA, H. J.; CUNHA, D. A. Considerações sobre o uso do paquímetro em motricidade oral. R. Fonoaudiol. Bras., Brasília (DF), v. 3, p. 59-64, dez. 2003.

SUGUINO, R.; RAMOS, A. L.; TERADA, H. H.; FRUQUIM, L. Z.; MAEDA, L.; SILVA FILHO, O. G. Análise facial. Dent. Press Ortodon. Ortop. Fac., Maringá (PR), v. 1, n. 1, p. 86-107, jan.-fev. 1996.

WARD, R. E.; JAMINSON, P. L.; FARKAS, L. G. Craniofacial variability in the head and face. Am. J. Med. Genet., New York, v. 80, p. 232-240, nov. 1998.

WARD, R. E.; JAMINSON, P. L.; ALLANSON, J. E. Quantitative approach to identifying abnormal variation in human face exemplified syndromes. Am. J. Med. Genet., New York, v. 91, n. 1, p. 8-17, mar. 2000. 